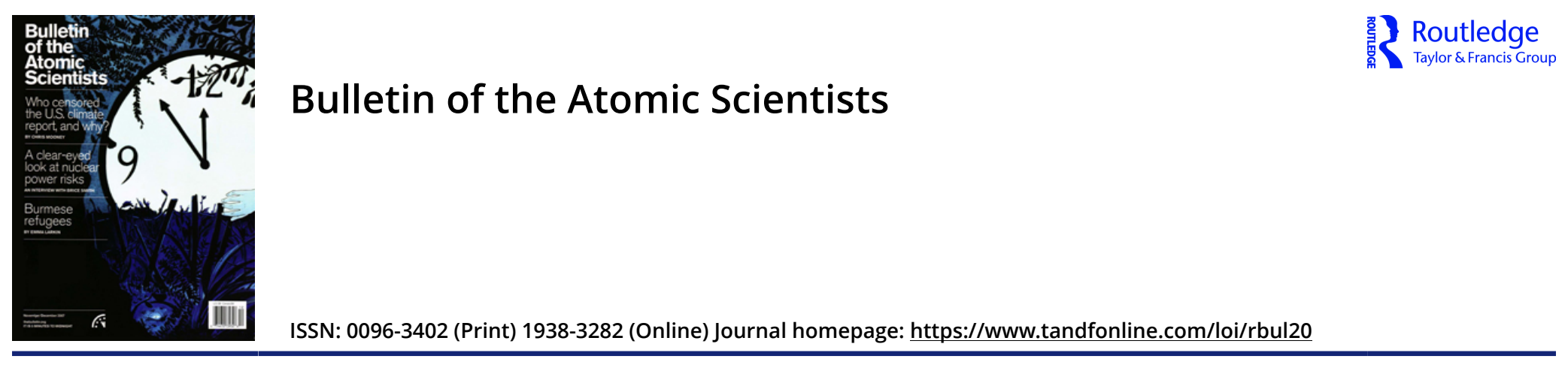

\title{
A Turkish Nuclear Turnaround
}

\section{Mustafa Kibaroglu}

To cite this article: Mustafa Kibaroglu (2007) A Turkish Nuclear Turnaround, Bulletin of the Atomic Scientists, 63:6, 64-64, DOI: 10.1080/00963402.2007.11461123

To link to this article: https://doi.org/10.1080/00963402.2007.11461123

\section{冓 Published online: 15 Sep 2015.}

Submit your article to this journal $\pi$

Цll Article views: 7 


\section{A TURKISH NUCLEAR TURNAROUND}

\section{BY MUSTAFA KIBAROGLU}

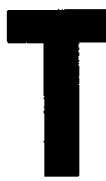

HE PROBABILITY THAT STATES or terrorist groups will detonate elaborate or crude nuclear devices increases with the spread of the materials and technology used in the manufacture of these weapons. Before it is too late, every nation must start thinking about effective ways to get rid of their existing nuclear arsenals.

To that end, Turkish officials should seriously consider returning the U.S. tactical nuclear weapons that have been deployed in Turkey since the 1960 s as part of NATO's nuclear posture. Turkish officials still believe these weapons have a deterrent value because the Middle East and the adjacent regions are far from being peaceful or stable due to the chaos in Iraq and the interminable Palestinian-Israeli conflict. Added to these concerns are the unknowns about Iran's nuclear capabilities and intentions, as well as Russia's negative stance regarding the implementation of the IntermediateRange Nuclear Forces Treaty and the 1990 Conventional Armed Forces in Europe Treaty.

Nevertheless, it should be acknowledged that nuclear weapons have become inappropriate in the face of the new threats posed to the free world by terrorist organizations. The sui generis conditions of the superpower rivalry during the Cold War period cannot and therefore should not be used as a pretext for keeping the existing

Mustafa Kibaroglu (kibar@bilkent.edu .tr) teaches in the Department of International Relations at Bilkent University in Ankara, Turkey. stockpiles of nuclear weapons or developing new ones.

New opportunities exist for taking region-wide initiatives such as revitalizing efforts to establish a nuclearweapon-free zone (NWZ) in the Middle East. Turkey has supported the idea of a regional NWZ since Iran and Egypt first proposed it to the United Nations in 1974. Yet, because Turkey was hosting U.S. nuclear weapons, Turkish officials did not consider becoming part of the zone. In a nod to geopolitical realities, other countries in the region did not insist on having Turkey on board either.

However, the tide has turned since the early 1990s, and Turkey has become more entrenched in Mideast regional player. Some Iranian security elite even go so far as to characterize Turkey as a "nuclear weapon state" due to the presence of U.S. weapons on its soil. This serves as yet another justification of their ambitions to develop nuclear weapons.

Sending back U.S. nuclear weapons will strengthen Turkey's position visà-vis the aspiring nuclear states in the region and will also improve the prospects of a NWZ in the Middle East. This decision would be perfectly compatible with Turkey's long-standing efforts to stem proliferation. As a significant regional military power and a NATO member, Turkey will also send a message to Israel, Iran, and the Arab states that nuclear weapons are no

\section{Sending back U.S. nuclear weapons will strengthen}

\section{Turkey's position and will also improve the prospects} of a Mideast nuclear-weapon-free zone.

politics. Dramatic events such as the 1991 Persian Gulf War and the collapse of the Soviet Union shifted Turkey's attention from its northeastern border to its southern border. Turkey started to play a more active role in the Palestinian question, thanks to its Muslim identity and its strategic relations with Israel. And since the overthrow of Saddam Hussein, the situation in Iraq has become the number one issue on Turkey's foreign policy agenda-primarily due to the uncertainty surrounding the future of northern Iraq, where the local Kurdish administration aspires to an independent state. Indeed, many analysts now see Turkey as a full-fledged longer vital for security considerations. Indeed, U.S. nuclear weapons have not been useful or instrumental in Turkey's fight against Kurdistan Workers' Party (PKK) terrorism over the last quartercentury. On the contrary, these weapons have aggravated the animosity of Turkey's neighbors, such as Syria, Iraq, and Iran, prompting them to increase their support for the PKK.

If the family of sovereign nations is lucky enough, it may not be too late to implement a number of sober-minded steps to get rid of existing nuclear weapons, wherever they may be stockpiled or deployed. A Turkish initiative could help lead the way. 